\title{
Description of Sphingosinicella xenopeptidilytica sp. nov., a $\beta$-peptide-degrading species, and emended descriptions of the genus Sphingosinicella and the species Sphingosinicella microcystinivorans
}

\author{
Birgit Geueke, ${ }^{1}$ Hans-Jürgen Busse, ${ }^{2}$ Thomas Fleischmann, ${ }^{1}$ \\ Peter Kämpfer ${ }^{3}$ and Hans-Peter E. Kohler ${ }^{1}$ \\ ${ }^{1}$ Swiss Federal Institute of Aquatic Science and Technology, Eawag, CH-8600 Dübendorf, \\ Switzerland \\ ${ }^{2}$ Institut für Bakteriologie, Mykologie und Hygiene, Veterinärmedizinische Universität, A-1210 \\ Wien, Austria \\ ${ }^{3}$ Institut für Angewandte Mikrobiologie, Justus-Liebig-Universität Giessen, D-35392 Giessen, \\ Germany
}

Correspondence Hans-Peter E. Kohler kohler@eawag.ch
The synthesis of $\beta$-peptides composed of $\beta$-homoamino acids with proteinogenic side-chains was achieved for the first time by Seebach et al. (1996). Since then, knowledge has accumulated about the structural properties of $\beta$-peptides, their synthesis on the basis of homologated $\beta$-amino acids (Seebach et al., 2004), their pharmaceutical applications

\footnotetext{
The GenBank/EMBL/DDBJ accession number for the 16S rRNA gene sequence of strain $3-2 W 4^{\top}$ is $A Y 950663$.

A two-dimensional thin-layer chromatogram of the polar lipids of strain $3-2 W 4^{\top}$ is available as a supplementary figure in IJSEM Online.
}

(Kritzer et al., 2004; Stephens et al., 2005) and their biological stability (Frackenpohl et al., 2001; Lelais \& Seebach, 2003; Seebach et al., 1998). $\beta$-Amino acids are found in many biological molecules, such as microcystin, paclitaxel (Taxol), carnosine and bestatin, but $\beta$-peptides composed solely of $\beta$-homoamino acids do not occur in nature. Although $\beta$-peptides are of synthetic origin and exhibit extremely high resistance to enzymic degradation, different bacterial consortia have been shown to have the capacity to grow on these substrates (Schreiber et al., 2002). Recently, strain $3-2 \mathrm{~W} 4^{\mathrm{T}}$ was isolated from one of these mixed cultures and it was shown that this strain utilized the 
$\beta$-tripeptide $\mathrm{H}-\beta \mathrm{hVal}-\beta \mathrm{hAla}-\beta \mathrm{hLeu}-\mathrm{OH}$ as a sole source of carbon and energy (Geueke et al., 2005). The inoculum for the enrichment culture originated from the aeration tank of a wastewater treatment plant at Leutschenbach in Zurich, Switzerland. Here we report on the classification of strain 3$2 \mathrm{~W} 4^{\mathrm{T}}$ within a novel species of Sphingosinicella, based on analyses of its $16 \mathrm{~S}$ rRNA gene sequence, chemotaxonomic characteristics and physiological traits.

Genomic DNA was extracted with the AquaPure genomic DNA purification kit (Bio-Rad). The 16S rRNA gene sequence of strain $3-2 \mathrm{~W} 4^{\mathrm{T}}$ was amplified by a PCR using the primers $16 \mathrm{~S}$ 6F (5'-GGAGAGTTAGATCTTGGCTCA-3') and 16S 1510R (5'-GTGCTGCAGGGTTACCTTGTTACGACT-3'). The PCR product was cloned into pGEM-T Easy, sequenced and a continuous stretch of $1411 \mathrm{bp}$ was obtained. The $16 \mathrm{~S}$ rRNA gene sequence of strain $3-2 \mathrm{~W} 4^{\mathrm{T}}$ was compared with sequences in the databases by means of a BLAST search: the highest levels of similarity were found with respect to Sphingosinicella microcystinivorans $\mathrm{Y}^{\mathrm{T}}{ }^{\mathrm{T}}$ (99.9\%) (Maruyama et al., 2006) and Sphingomonas suberifaciens IFO $15211^{\mathrm{T}}(94.6 \%)$, the latter being a strain that will probably be classified within another genus on the basis of its separate phylogenetic position. Values of $\leqslant 94.2 \%$ were found with respect to the type strains of Sphingomonas and Sphingopyxis species. Like Sphingosinicella microcystinivorans $\mathrm{Y}^{\mathrm{T}}{ }^{\mathrm{T}}$, strain $3-2 \mathrm{~W} 4^{\mathrm{T}}$ exhibited all of the characteristic $16 \mathrm{~S}$ rRNA signature nucleotides of the genus Sphingomonas and showed a single difference with respect to the signatures of the genus Sphingopyxis (Takeuchi et al., 2001). Additionally, we identified eight signature nucleotides that distinguish Sphingosinicella strains from other members of the

Table 1. Signatures in the $16 \mathrm{~S}$ rRNA gene sequences of Sphingosinicella strains (including unnamed strains sharing more than $97 \%$ similarity with Sphingosinicella microcystinivorans $\mathrm{Y}^{\top}{ }^{\top}$ ) useful for differentiation from all other species of the family Sphingomonadaceae

Positions are given according to Escherichia coli numbering.

\begin{tabular}{|lcc|}
\hline Position & $\begin{array}{c}\text { Sphingosinicella } \\
\text { of the Sphingomonadaceae }\end{array}$ & $\begin{array}{c}\text { Other members } \\
\text { Sphos }\end{array}$ \\
\hline 412 & $\mathrm{~A}$ & $\mathrm{U}$ \\
562 & $\mathrm{C}$ & $\mathrm{U}$ \\
748 & $\mathrm{~A}$ & $\mathrm{U}$ \\
823 & $\mathrm{G}$ & $\mathrm{A} \dagger$ \\
877 & $\mathrm{C}$ & $\mathrm{C} \ddagger$ \\
841 & $\mathrm{U}$ & $\mathrm{U}$ or CS \\
1463 & $\mathrm{~A}$ & $\mathrm{G}$ or A \\
1438 & $\mathrm{U}$ & \\
\hline
\end{tabular}

${ }^{*} \mathrm{G}$ for Sphingomonas phyllosphaerae, A for Sphingomonas suberifaciens. $\dagger \mathrm{U}$ for Sphingomonas echinoides.

¥A for Sphingopyxis baekryungensis; gap for most Novosphingobium strains.

$\S \mathrm{G}$ for Sphingomonas echinoides.
Sphingomonadaceae (Table 1). Phylogenetic analysis of nearly full-length $16 \mathrm{~S}$ rRNA gene sequences of strain 3$2 \mathrm{~W} 4^{\mathrm{T}}$ and Sphingosinicella microcystinivorans $\mathrm{Y}^{\mathrm{T}}$ confirmed that they are closely related to each other and that the genus Sphingosinicella forms a distinct phylogenetic lineage in comparisons with selected type strains of the family Sphingomonadaceae (Fig. 1).

Strain $3-2 \mathrm{~W} 4^{\mathrm{T}}$ was subcultured on nutrient agar (Biolife) at $30{ }^{\circ} \mathrm{C}$. Liquid cultures were incubated at $25^{\circ} \mathrm{C}$ in nutrient broth or minimal medium. The minimal medium used to measure the $\mathrm{pH}$ and $\mathrm{NaCl}$ tolerances was composed of the following $\left(1^{-1}\right): 0.2 \mathrm{mM} \mathrm{CaCl}_{2}, 2 \mathrm{mM} \mathrm{MgSO}_{4}, 1 \mathrm{~g} \mathrm{NaCl}_{2} 2 \mathrm{~g}$ $\mathrm{Na}_{2} \mathrm{HPO}_{4} \cdot 2 \mathrm{H}_{2} \mathrm{O}, 1 \mathrm{~g} \mathrm{KH}_{2} \mathrm{PO}_{4}, 0.7 \mathrm{~g}\left(\mathrm{NH}_{4}\right)_{2} \mathrm{SO}_{4}$ and $0.1 \mathrm{~g}$ yeast extract. It was supplemented with a trace element solution $\left(1 \mathrm{ml} \mathrm{l}^{-1}\right)$ and a vitamin solution $\left(2 \mathrm{ml} \mathrm{l}^{-1}\right)$ according to Schreiber et al. (2002). $\mathrm{NaCl}$ and $\mathrm{pH}$ tolerances were measured in minimal medium with isoleucine $\left(1 \mathrm{~g} \mathrm{l}^{-1}\right)$ as the main carbon source. To adjust the $\mathrm{pH}$ of the medium, the phosphate salts were omitted and universal buffer (according to Teorell \& Stenhagen, 1938) was used for $\mathrm{pHs}$ in the range 4-12. Growth at different salinities was measured for $\mathrm{NaCl}$ concentrations between 0 and $3 \%(\mathrm{w} / \mathrm{v})$. Carbon-source utilization was examined as described

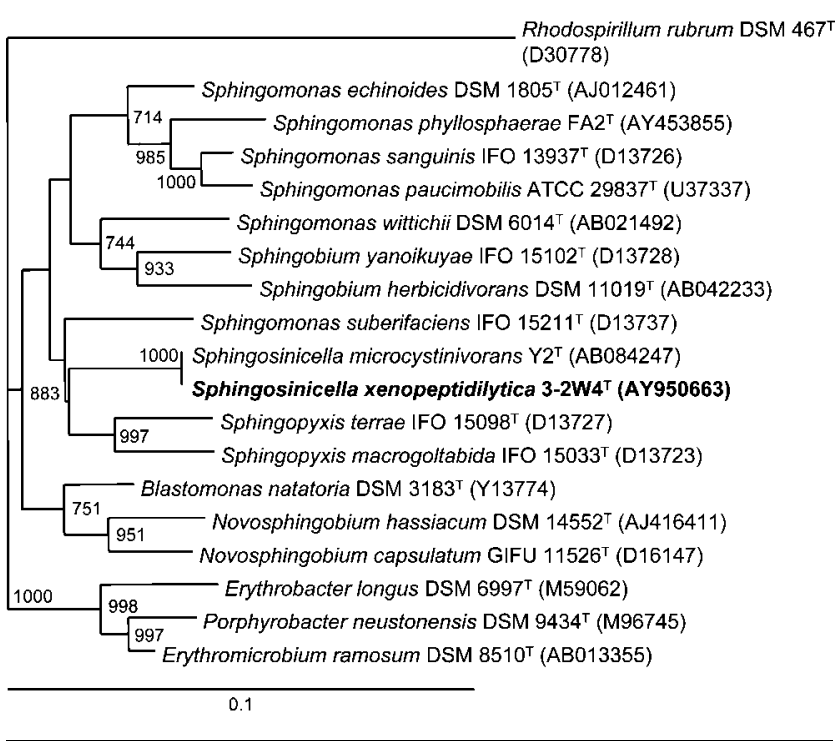

Fig. 1. Neighbour-joining phylogenetic tree of the type strains of the genus Sphingosinicella and selected type strains of the genera Sphingomonas, Sphingopyxis, Novosphingobium, Sphingobium and other members of the Alphaproteobacteria. Rhodospirillum rubrum DSM $467^{\top}$ was used as the outgroup. The alignment was performed with the program CLUSTAL W (Chenna et al., 2003) and ambiguous nucleotides and gaps were removed with the program BioEdit, version 5.0.6. The total alignment length was $1299 \mathrm{bp}$. Phylogenetic analyses were performed using the PHYLIP package (version 3.6). Numbers at the nodes show bootstrap values higher than 700, based on DNA distance analyses of 1000 resampled datasets. Bar, 0.1 substitutions per nucleotide position. 
previously (Kämpfer et al., 1991). Additionally, physiological and biochemical characteristics were examined using the API 20NE and API 20E kits according to the manufacturer's instructions (bioMérieux). Gram stains were performed at the Deutsche Sammlung von Mikroorganismen und Zellkulturen (DSMZ; Braunschweig, Germany) according to Cerny (1976) and Gregersen (1978); the hydrolysis of starch, Tween 80 and DNA was measured according to Gerhardt et al. (1981). Strain 3-2W4 ${ }^{\mathrm{T}}$ and Sphingosinicella microcystinivorans $\mathrm{Y}^{\mathrm{T}}$ utilized many amino acids and some organic acids as sources of carbon and energy, but they did not grow on any of the sugars and polyalcohols tested (Table 2). The only characteristics that distinguish strain $3-2 \mathrm{~W} 4^{\mathrm{T}}$ from Sphingosinicella microcystinivorans $\mathrm{Y} 2^{\mathrm{T}}$ concerned the intensity of growth on $\beta$-homovaline, citrate and DL-lactate and the reduction of nitrate to nitrite (Table 2).

Recently, the $\beta$-peptidyl aminopeptidase of strain $3-2 \mathrm{~W} 4^{\mathrm{T}}$ was isolated and characterized and its coding sequence (bapA) analysed (Geueke et al., 2005). This enzyme is responsible for the ability of strain $3-2 \mathrm{~W} 4^{\mathrm{T}}$ to utilize the synthetic $\beta$-peptides $\mathrm{H}-\beta$ hVal- $\beta$ hLeu- $\beta$ hAla-OH and $\mathrm{H}$ $\beta$ hAla- $\beta$ hLeu-OH as sole sources of carbon, nitrogen and energy (Geueke et al., 2005). The two $\beta$-peptides were synthesized according to Schreiber et al. (2002). To determine whether this unusual enzymic activity might be characteristic of the genus Sphingosinicella, Sphingosinicella microcystinivorans $\mathrm{Y}^{\mathrm{T}}, 20$ type strains of Sphingomonas and six type strains of Sphingopyxis species were tested for the ability to utilize both $\beta$-peptides as sole sources of carbon and energy. Strain $3-2 \mathrm{~W} 4^{\mathrm{T}}$ and Sphingosinicella microcystinivorans $\mathrm{Y}^{\mathrm{T}}$ assimilated the two $\beta$-peptides, but none of the reference strains did. Moreover, a copy of the bapA gene was detected in the genome of Sphingosinicella microcystinivorans $\mathrm{Y}^{\mathrm{T}}$ (Geueke et al., 2006). These observations indicate that utilization of $\beta$-peptides distinguishes strain $3-2 \mathrm{~W} 4^{\mathrm{T}}$ and Sphingosinicella microcystinivorans $\mathrm{Y}^{\mathrm{T}}$ from Sphingomonas and Sphingopyxis species.

The degradation of microcystin by strain $3-2 \mathrm{~W}^{\mathrm{T}}$ was investigated, since this feature is an exceptional trait of Sphingosinicella microcystinivorans (Maruyama et al., 2006; Park et al., 2001; Saito et al., 2003). Strain $3-2 \mathrm{~W}^{\mathrm{T}}$ was cultivated in nutrient broth, the cells were harvested in the late-exponential phase by centrifugation and disrupted by ultrasonication and the crude extract was incubated with microcystin-LR, which is the most common type of microcystin. Under these conditions, no degradation was observed. To support this result, we screened for the occurrence of the genes $m l r A, m l r B, m l r C$ and $m l r D$, because they code for three peptidases and an oligopeptide transporter protein that are involved in the degradation of microcystin (Bourne et al., 2001; Saito et al., 2003). The following primer pairs were used to probe for the $m l r A$, $m l r B, \quad m l r C$ and $m l r D$ genes, respectively: $5^{\prime}$ GACCCGATGTTCAAGATGCT- $3^{\prime}$ and $5^{\prime}$-CTCCTCCCACAAATCAGGAC-3'; 5' -ACNTCGAAGCAGTTTACAGC-3'
Table 2. Characteristics of strain $3-2 \mathrm{~W} 4^{\top}$ useful for differentiation from Sphingosinicella microcystinivorans $\mathrm{Y}^{\top}$

Strains: $1,3-2 \mathrm{~W} 4^{\mathrm{T}} ; 2$, Sphingosinicella microcystinivorans $\mathrm{Y}^{\mathrm{T}}{ }^{\mathrm{T}}+$, Positive; -, negative; $(+)$, weakly positive. Both strains grew on acetate, azelate, 4-aminobutyrate, DL-3-hydroxybutyrate, propionate, suberate, L-alanine, L-aspartate, L-histidine, L-leucine, Lornithine, L-phenylalanine, L-serine, L-tryptophan, L-valine, $\beta$-alanine, L- $\beta$-homoalanine, L- $\beta$-homoleucine, L- $\beta$-homovaline, L-isoleucine, L-glutamate, L-arginine, L-lysine, L-proline, L-threonine, but not on $\mathrm{N}$-acetylgalactosamine, $\mathrm{N}$-acetyl-D-glucosamine, L-arabinose, $p$-arbutin, D-cellobiose, D-fructose, D-galactose, D-glucose, D-mannose, D-maltose, $\alpha$-D-melibiose, L-rhamnose, D-ribose, sucrose, salicin, D-trehalose, D-xylose, adonitol, i-inositol, maltitol, D-mannitol, D-sorbitol, putrescine, cis- and trans-aconitate, glycerol, adipate, caprate, fumarate, gluconate, itaconate, malate, mesaconate, oxoglutarate, succinate, L-cysteine, L-tyrosine, Lmethionine, glycine, glycyl-glycine, 3-hydroxybenzoate or 4-hydroxybenzoate. Both strains hydrolysed bis- $p$-nitrophenyl phosphate, $p$-nitrophenyl phenylphosphonate, $p$-nitrophenyl phosphorylcholine, 2-deoxythymidine $5^{\prime}$-p-nitrophenyl phosphate, L-alanine $p$ nitroanilide, L-glutamate- $\gamma$-3-carboxy $p$-nitroanilide and L-proline $p$-nitroanilide, but not aesculin, gelatin, $o$-nitrophenyl $\beta$-D-galactopyranoside, $p$-nitrophenyl $\beta$-D-glucuronide, $p$-nitrophenyl $\alpha$-D-glucopyranoside, $p$-nitrophenyl $\beta$-D-glucopyranoside or $p$-nitrophenyl $\beta$-D-xylopyranoside. They did not exhibit urease or arginine dihydrolase activity. They were unable to produce acid from glucose, lactose, sucrose, D-mannitol, dulcitol, salicin, adonitol, inositol, sorbitol, L-arabinose, raffinose, rhamnose, maltose, D-xylose, trehalose, cellobiose, methyl D-glucoside, erythritol, melibiose, D-arabitol and D-mannose. Formation of indole from tryptophan was not detected for either strain. Both strains grew on R2A agar plates and exhibited positive reactions for oxidase and catalase activities. The genes bapA and $m l r D$ were detected by PCR in both strains, but $m l r C$ did not yield a PCR product in either strain.

\begin{tabular}{|lcc|}
\hline Characteristic & $\mathbf{1}$ & $\mathbf{2}$ \\
\hline Assimilation of: & & \\
DL-Lactate & + & $(+)$ \\
Citrate & + & $(+)$ \\
L- $\beta$-Homovaline & $(+)$ & + \\
Reduction of nitrate & + & - \\
Degradation of microcystin & - & + \\
Two red pigment spots in the polar lipid extract & + & - \\
Growth at $2.5 \%$ (w/v) NaCl & + & - \\
Detection by PCR of: & & \\
$m l r A$ & - & + \\
$m l r B$ & - & + \\
$p u f$ & - & + \\
\hline
\end{tabular}

and $5^{\prime}$-AAGTAATTGGTGTTDACGTA-3' $; 5^{\prime}$-AATWCNTTCTCACCTSTGCC- $3^{\prime}$ and 5'-CCACCGCCGGGGT-

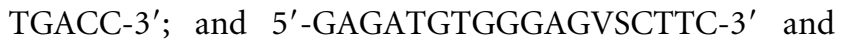
5'-CCMAGWGTGCCGCAGAYCAGCGG-3'. Genes $m l r A$, $m l r B$ and $m l r C$, which encode enzymes responsible for the degradation of microcystin, were not detected in the genome of strain $3-2 \mathrm{~W} 4^{\mathrm{T}}$, but $m l r A, m l r B$ and $m l r D$ were 
present in strain $\mathrm{Y}^{\mathrm{T}}$ (Table 2). Additionally, the absence of $m l r A$ in strain $3-2 \mathrm{~W}^{\mathrm{T}}$ was demonstrated by Southern hybridization with DIG-High Prime DNA Labelling and Detection starter kit II (Roche). The probe was composed of $806 \mathrm{bp}$ and was amplified from genomic DNA of strain $\mathrm{Y}^{\mathrm{T}}$ by a PCR using the above-mentioned primers. From the results of the degradation and genetic experiments, we can conclude that strain $3-2 \mathrm{~W} 4^{\mathrm{T}}$ is not capable of utilizing microcystin.

PCR experiments with the genomic DNA of Sphingosinicella microcystinivorans $\mathrm{Y}^{\mathrm{T}}$ and strain $3-2 \mathrm{~W} 4^{\mathrm{T}}$ and the primers 5'-TGTCCGAGATCATCACSRTYTGC-3' and 5' ${ }^{\prime}$-TTGCCGTABCGGATCGAGAA-3' showed that the former contained puf genes, which encode subunits of the photosynthetic reaction centre. These genes could not be detected in strain $3-2 \mathrm{~W} 4^{\mathrm{T}}$ (Table 2).

For the analysis of quinones, polar lipids and polyamines, the cells were cultivated aerobically in PYE medium $(0.3 \%$, $\mathrm{w} / \mathrm{v}$, casein peptone; $0.3 \%$, w/v, yeast extract; $\mathrm{pH} 7.2$ ) at $25^{\circ} \mathrm{C}$. Respiratory quinones and polar lipids were determined according to Tindall (1990) and Altenburger et al. (1996); polyamines were analysed according to Busse \& Auling (1988) and Busse et al. (1997). Fatty acids were analysed at the DSMZ with the MIDI Sherlock Microbial Identification System (version 4.5). The fatty acids of strain $3-2 \mathrm{~W} 4^{\mathrm{T}}$ comprised $\mathrm{C}_{18: 1} \omega 7 c(42.1 \%)$, summed feature 3 $\left(\mathrm{C}_{16: 1} \omega 7 c\right.$ and/or iso- $\left.\mathrm{C}_{15: 0} 2-\mathrm{OH}\right)(35.9 \%), \mathrm{C}_{16: 0}(10.5 \%)$, $\mathrm{C}_{14: 0} 2-\mathrm{OH}(4.3 \%), \mathrm{C}_{16: 1} \omega 5 c(3.2 \%)$ and $\mathrm{C}_{14: 0}(1.1 \%)$. Traces $(\leqslant 1 \%)$ of $\mathrm{C}_{17: 1} \omega 6 c, \mathrm{C}_{18: 1} \omega 5 c$, iso- $\mathrm{C}_{16: 0} 3-\mathrm{OH}$ and 11-methyl $\mathrm{C}_{18: 1} \omega 7 c$ were detected. A very similar fatty acid profile was detected for Sphingosinicella microcystinivorans $\mathrm{Y}^{\mathrm{T}}: \mathrm{C}_{18: 1} \omega 7 c(45.2 \%)$, summed feature $3\left(\mathrm{C}_{16: 1} \omega 7 c\right.$ and/ or iso- $\left.\mathrm{C}_{15: 0} 2-\mathrm{OH}\right)(31.9 \%), \mathrm{C}_{16: 0}(7.0 \%), \mathrm{C}_{14: 0} 2-\mathrm{OH}$ $(7.5 \%), \mathrm{C}_{16: 1} \omega 5 c(3.4 \%), \mathrm{C}_{14: 0}(1.5 \%), \mathrm{C}_{17: 1} \omega 6 c(1.4 \%)$ and $\mathrm{C}_{18: 1} \omega 5 c(1.2 \%)$. Traces $(<0.7 \%)$ of $\mathrm{C}_{16: 0} 2-\mathrm{OH}$, $\mathrm{C}_{18: 1} \omega 5 c$, iso- $\mathrm{C}_{16: 0} 3-\mathrm{OH}$ and $\mathrm{C}_{18: 0}$ were identified. This result was also in excellent agreement with data reported for Sphingosinicella microcystinivorans (Maruyama et al., 2006). The quinone system of strain $3-2 \mathrm{~W} 4^{\mathrm{T}}$ consisted exclusively of ubiquinone Q-10 and the predominant polyamine was sym-homospermidine, both of which are characteristic of the genera Sphingomonas sensu stricto and Sphingosinicella (Busse et al., 1999; Maruyama et al., 2006; Takeuchi et al., 2001). The polar lipid profiles of strain $3-2 \mathrm{~W}^{\mathrm{T}}$ and Sphingosinicella microcystinivorans $\mathrm{Y}^{\mathrm{T}}$ were almost identical, confirming their high degree of relatedness. They consisted of the major compounds phosphatidylethanolamine, phosphatidylmonomethylethanolamine, phosphatidylglycerol and sphingoglycolipid, moderate amounts of diphosphatidylglycerol and minor to trace amounts of two unknown phospholipids, an unknown aminophospholipid and an unknown polar lipid. One of the unknown phospholipids showed the same chromatographic behaviour as PL3, which is present in the majority of species of the Sphingomonadaceae, as reported by Busse et al. (1999). Within the family Sphingomonadaceae, the lack of phosphatidyldimethylethanolamine in polar lipid extracts has been reported only for Sphingomonas echinoides DSM $1805^{\mathrm{T}}$, Sphingopyxis witflariensis DSM $14551^{\mathrm{T}}$ and Sphingopyxis macrogoltabidus DSM $8826^{\mathrm{T}}$; Sphingomonas echinoides DSM $1805^{\mathrm{T}}$ was the only strain also lacking phosphatidylcholine. These observations, as well as the presence of the major compound phosphatidylmonomethylamine, underscore the unique polar lipid profiles of strain 3$2 \mathrm{~W} 4^{\mathrm{T}}$ and Sphingosinicella microcystinivorans $\mathrm{Y}^{\mathrm{T}}$ (Busse et al., 1999, 2003, 2005; Denner et al., 2001; Kämpfer et al., 2002b, c; Liu et al., 2005; Pal et al., 2005; Tiirola et al., 2005; Zhang et al., 2005). Hence, this characteristic might be specific for members of the genus Sphingosinicella. However, this assumption has to be verified by isolating and analysing further species of the genus. The presence of two red pigment spots in addition to two yellow spots visible after twodimensional TLC of the lipid extract clearly distinguished strain $3-2 \mathrm{~W} 4^{\mathrm{T}}$ from Sphingosinicella microcystinivorans $\mathrm{Y}^{\mathrm{T}}$ (see Supplementary Fig. S1 available in IJSEM Online).

DNA-association studies were performed between strain 3$2 \mathrm{~W} 4^{\mathrm{T}}$ and Sphingosinicella microcystinivorans $\mathrm{Y}^{\mathrm{T}}$ using two different methods. The microplate method described by Ziemke et al. (1998) was modified slightly: for nick translation, $2 \mu \mathrm{g}$ DNA was labelled for $3 \mathrm{~h}$ at $15^{\circ} \mathrm{C}$. The second DNA-DNA hybridization experiment (De Ley et al., 1970; Huß et al., 1983) was performed by the identification service of the DSMZ. With the microplate method, strain 3$2 \mathrm{~W} 4^{\mathrm{T}}$ and Sphingosinicella microcystinivorans $\mathrm{Y}^{\mathrm{T}}$ exhibited $40.6 \%$ (reciprocal, 51.9\%) DNA-DNA relatedness, whereas hybridization experiments performed at the DSMZ resulted in $33 \pm 7 \%$ DNA-DNA relatedness. These observations confirmed the results of a previous study that reported slightly higher hybridization results when the microplate method was used (Kämpfer et al., 2002a). However, the results clearly indicate that the two strains belong to different species, despite their almost identical $16 \mathrm{~S}$ rRNA gene sequences.

We performed PCRs using the repetitive primers BOX, ERIC and REP to fingerprint the genomes of strain 3-2W $4^{\mathrm{T}}$ and Sphingosinicella microcystinivorans $\mathrm{Y}^{\mathrm{T}}$ using Expand long template polymerase (Roche Diagnostics) and primers REP1R-I, REP2-I, ERIC1R, ERIC2 and BOXA1R (Louws et al., 1994). The banding patterns from these PCR experiments clearly showed differences between the two strains (Fig. 2). A band of approximately $1.9 \mathrm{~kb}$ became visible for both strains after BOX-PCR; this band was much more prominent for strain $3-2 \mathrm{~W} 4^{\mathrm{T}}$, whereas additional products appeared for Sphingosinicella microcystinivorans $\mathrm{Y}^{\mathrm{T}}{ }^{\mathrm{T}}$. The fingerprints after ERIC-PCR and REP-PCR show striking differences. However, the REP-fingerprint of both strains exhibited two bands of approximately $1.2-1.3 \mathrm{~kb}$.

The high levels of 16S rRNA gene sequence similarity and the similar chemotaxonomic features for strain $3-2 \mathrm{~W} 4^{\mathrm{T}}$ and Sphingosinicella microcystinivorans $\mathrm{Y} 2^{\mathrm{T}}$ showed that strain 3$2 \mathrm{~W} 4^{\mathrm{T}}$ should be classified within the genus Sphingosinicella. Moreover, our experiments indicated that strain $3-2 \mathrm{~W} 4^{\mathrm{T}}$ is unable to degrade microcystin, in contrast to 


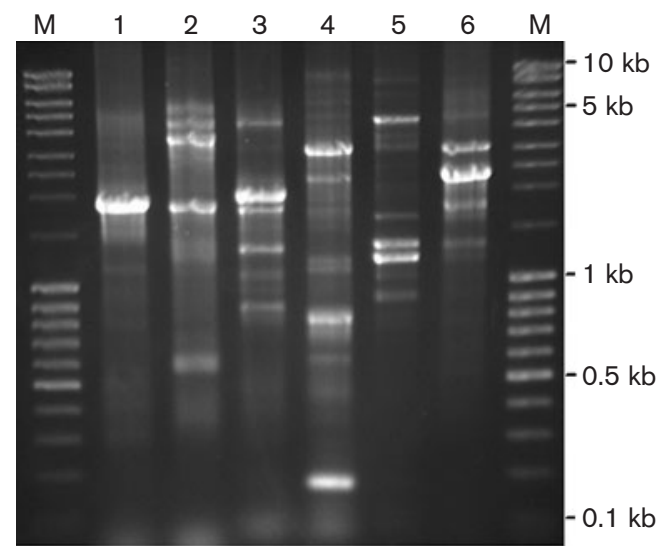

Fig. 2. $P C R$ fingerprints from genomic DNA of strain $3-2 W 4^{\top}$ and Sphingosinicella microcystinivorans $\mathrm{Y}^{\top}$. The BOX-PCR (lanes 1 and 2), ERIC-PCR (lanes 3 and 4) and REP-PCR (lanes 5 and 6) patterns are shown. The resulting electrophoretic patterns of strain $3-2 \mathrm{~W} 4^{\top}$ (lanes 1, 3 and 5) and Sphingosinicella microcystinivorans $\mathrm{Y}^{\top}{ }^{\top}$ (lanes 2, 4 and 6) are illustrated. The PCR program was started with one initial cycle at $94{ }^{\circ} \mathrm{C}$ for $2 \mathrm{~min}$, followed by 10 cycles of denaturation at $94{ }^{\circ} \mathrm{C}$ for $10 \mathrm{~s}$, annealing at 44,52 or $53^{\circ} \mathrm{C}$ for $30 \mathrm{~s}$ with the REP, ERIC and BOX primers, respectively, and extension at $68^{\circ} \mathrm{C}$ for $4 \mathrm{~min}$. The elongation times for the next 25 cycles were extended to $4 \mathrm{~min}$ plus $20 \mathrm{~s}$ for each successive cycle. The reaction was stopped after subsequent incubation at $68^{\circ} \mathrm{C}$ for $7 \mathrm{~min}$. The gel was loaded with $5 \mu \mathrm{l}$ PCR mixture. M, Markers.

Sphingosinicella microcystinivorans, for which this capacity is a major characteristic (Maruyama et al., 2006). In view of the results of the DNA-DNA hybridization experiments between strain $3-2 \mathrm{~W} 4^{\mathrm{T}}$ and Sphingosinicella microcystinivorans $\mathrm{Y} 2^{\mathrm{T}}$, the absence of genes important in the degradation of microcystin, the presence of two red compounds in the pigment composition and the ability to reduce nitrate show that strain $3-2 \mathrm{~W}^{\mathrm{T}}$ represents a novel species of the genus Sphingosinicella, for which we propose the name Sphingosinicella xenopeptidilytica sp. nov.

In this study, we have demonstrated that Sphingosinicella xenopeptidilytica 3-2W4 $4^{\mathrm{T}}$ and Sphingosinicella microcystinivorans $\mathrm{Y} 2^{\mathrm{T}}$ utilize the $\beta$-peptides $\mathrm{H}$ - $\beta$ hVal- $\beta$ hLeu- $\beta$ hAla$\mathrm{OH}$ and $\mathrm{H}-\beta$ hAla- $\beta$ hLeu-OH as sole carbon and energy sources. Growth on these unusual substrates is the only trait that distinguishes the two strains from strains of the genera Sphingopyxis and Sphingomonas sensu stricto. In addition, we have provided the complete polar lipid profiles of these two strains. In view of these findings, an emended description of the genus Sphingosinicella is justified and is given below.

\section{Emended description of Sphingosinicella Maruyama et al. 2006}

The genus is as described by Maruyama et al. (2006), with the following emendations and modifications. Cells utilize the $\beta$-peptides $\mathrm{H}$ - $\beta$ hVal- $\beta$ hAla- $\beta$ hLeu-OH and $\mathrm{H}-\beta$ hAla$\beta$ hLeu-OH as sole carbon and energy sources and exhibit $\beta$ peptidyl aminopeptidase activity. The polar lipid profiles comprise the major compounds phosphatidylethanolamine, phosphatidylmonomethylethanolamine, phosphatidylglycerol and sphingoglycolipid, moderate amounts of diphosphatidylglycerol and minor to trace amounts of two unknown phospholipids, an unknown aminolipid and an unknown polar lipid. Eight nucleotides of the $16 \mathrm{~S}$ rRNA gene sequence are typical signatures (Table 1). Degradation of microcystin is variable among species.

\section{Emended description of Sphingosinicella microcystinivorans Maruyama et al. 2006}

The species shares the characteristics listed in the emended genus description. Data listed in Table 2 add to the original species description. Growth is observed at temperatures in the range $20-37^{\circ} \mathrm{C}$, at $\mathrm{pH} 5.6$ and 9.7 and at 0 and $2 \% \mathrm{NaCl}$ (w/v).

\section{Description of Sphingosinicella xenopeptidilytica sp. nov.}

Sphingosinicella xenopeptidilytica [xe'no.pep'ti.di.ly'ti.ca. Gr. adj. xenos foreign; N.L. n. peptidum peptide; N.L. adj. lyticus - a -um dissolving; N.L. fem. adj. xenopeptidilytica lysing foreign (xenobiotic) peptides].

Colonies are pale yellow, circular and convex. Cells are aerobic and $0.6-0.8 \times 1.5-2.5 \mu \mathrm{m}$ in size. Gram-negative, as determined by $\mathrm{KOH}$ and aminopeptidase tests. Growth occurs at temperatures between 5 and $37^{\circ} \mathrm{C}$, with an optimum between 20 and $37^{\circ} \mathrm{C}$ on nutrient agar, but not at $44{ }^{\circ} \mathrm{C}$. Cells grow in liquid minimal medium at $\mathrm{pH}$ 5.6-9.7 and at salinities of $0-2.5 \%(\mathrm{w} / \mathrm{v})$ but not at higher $\mathrm{NaCl}$ concentrations or on Bacto marine agar 2216 (Becton Dickinson). $\mathrm{H}_{2} \mathrm{~S}$ is formed. Starch, Tween 80 and DNA are not hydrolysed. Microcystin is not degraded and the relevant genes, $m l r A, m l r B$ and $m l r C$, are not present. Other physiological and biochemical characteristics are shown in Table 2 . The main fatty acids are $\mathrm{C}_{18: 1} \omega 7 c$, summed feature $3\left(\mathrm{C}_{16: 1} \omega 7 c\right.$ and/or iso- $\left.\mathrm{C}_{15: 0} 2-\mathrm{OH}\right)$ and $\mathrm{C}_{16: 0}$. The polar lipid profile is the same as that given in the emended genus description. The quinone system is ubiquinone Q-10 and the predominant polyamine is symhomospermidine. In addition to yellow components, the pigment composition contains also two red spots.

The type strain, $3-2 \mathrm{~W} 4^{\mathrm{T}}\left(\mathrm{DSM} 17130^{\mathrm{T}}=\mathrm{CCUG} 52537^{\mathrm{T}}\right)$, was isolated from the aeration tank of a wastewater treatment plant in Zürich, Switzerland.

\section{Acknowledgements}

This work was supported financially by the Swiss National Science Foundation (315200-109414/1 to B. G.). We are grateful to Linda Lawton for measuring microcystin degradation. 


\section{References}

Altenburger, P., Kämpfer, P., Makristathis, A., Lubitz, W. \& Busse, H. J. (1996). Classification of bacteria isolated from a medieval wall painting. J Biotechnol 47, 39-52.

Bourne, D. G., Riddles, P., Jones, G. J., Smith, W. \& Blakeley, R. L. (2001). Characterisation of a gene cluster involved in bacterial degradation of the cyanobacterial toxin microcystin LR. Environ Toxicol 16, 523-534.

Busse, H. J. \& Auling, G. (1988). Polyamine pattern as a chemotaxonomic marker within the Proteobacteria. Syst Appl Microbiol 11, 1-8.

Busse, H. J., Bunka, S., Hensel, A. \& Lubitz, W. (1997). Discrimination of members of the family Pasteurellaceae based on polyamine patterns. Int J Syst Bacteriol 47, 698-708.

Busse, H. J., Kämpfer, P. \& Denner, E. B. (1999). Chemotaxonomic characterisation of Sphingomonas. J Ind Microbiol Biotechnol 23, 242-251.

Busse, H. J., Denner, E. B., Buczolits, S., Salkinoja-Salonen, M., Bennasar, A. \& Kämpfer, P. (2003). Sphingomonas aurantiaca sp. nov., Sphingomonas aerolata sp. nov. and Sphingomonas faeni sp. nov., air- and dustborne and Antarctic, orange-pigmented, psychrotolerant bacteria, and emended description of the genus Sphingomonas. Int J Syst Evol Microbiol 53, 1253-1260.

Busse, H. J., Hauser, E. \& Kämpfer, P. (2005). Description of two novel species, Sphingomonas abaci sp. nov. and Sphingomonas panni sp. nov. Int J Syst Evol Microbiol 55, 2565-2569.

Cerny, G. (1976). Method for distinction of the gram-negative from gram-positive bacteria. Eur J App Microbiol 3, 223-225.

Chenna, R., Sugawara, H., Koike, T., Lopez, R., Gibson, T. J., Higgins, D. G. \& Thompson, J. D. (2003). Multiple sequence alignment with the Clustal series of programs. Nucleic Acids Res 31, 3497-3500.

De Ley, J., Cattoir, H. \& Reynaerts, A. (1970). The quantitative measurement of DNA hybridization from renaturation rates. Eur J Biochem 12, 133-142.

Denner, E. B. M., Paukner, S., Kämpfer, P., Moore, E. R. B., Abraham, W. R., Busse, H.-J., Wanner, G. \& Lubitz, W. (2001). Sphingomonas pituitosa sp. nov., an exopolysaccharide-producing bacterium that secretes an unusual type of sphingan. Int J Syst Evol Microbiol 51, 827-841.

Frackenpohl, J., Arvidsson, P. I., Schreiber, J. V. \& Seebach, D. (2001). The outstanding biological stability of $\beta$ - and $\gamma$-peptides toward proteolytic enzymes: an in vitro investigation with fifteen peptidases. Chembiochem 2, 445-455.

Gerhardt, P., Murray, R. G. E., Costilow, R. N., Nester, E. W., Wood, W. A., Krieg, N. R. \& Phillips, G. B. (editors) (1981). Manual of Methods for General Bacteriology. Washington, DC: American Society for Microbiology.

Geueke, B., Namoto, K., Seebach, D. \& Kohler, H.-P. E. (2005). A novel $\beta$-peptidyl aminopeptidase (BapA) from strain 3-2W4 cleaves peptide bonds of synthetic $\beta$-tri- and $\beta$-dipeptides. J Bacteriol 187, 5910-5917.

Geueke, B., Heck, T., Limbach, M., Nesatyy, V., Seebach, D. \& Kohler, H.-P. E. (2006). Bacterial $\beta$-peptidyl aminopeptidases with unique substrate specificities for $\beta$ - and mixed $\beta, \alpha$-oligopeptides. FEBS J 273, 5261-5272.

Gregersen, T. (1978). Rapid method for distinction of gramnegative from gram-positive bacteria. Eur J Appl Microbiol Biotechnol 5, 123-127.

Huß, V. A. R., Festl, H. \& Schleifer, K. H. (1983). Studies on the spectrophotometric determination of DNA hybridization from renaturation rates. Syst Appl Microbiol 4, 184-192.

Kämpfer, P., Steiof, M. \& Dott, W. (1991). Microbiological characterization of a fuel-oil contaminated site including numerical identification of heterotrophic water and soil bacteria. Microb Ecol 21, 227-251.

Kämpfer, P., Neef, A., Salkinoja-Salonen, M. S. \& Busse, H.-J. (2002a). Chelatobacter heintzii (Auling et al. 1993) is a later subjective synonym of Aminobacter aminovorans (Urakami et al. 1992). Int J Syst Evol Microbiol 52, 835-839.

Kämpfer, P., Witzenberger, R., Denner, E. B., Busse, H.-J. \& Neef, A. (2002b). Sphingopyxis witflariensis sp. nov., isolated from activated sludge. Int J Syst Evol Microbiol 52, 2029-2034.

Kämpfer, P., Witzenberger, R., Denner, E. B., Busse, H.-J. \& Neef, A. (2002c). Novosphingobium hassiacum sp. nov., a new species isolated from an aerated sewage pond. Syst Appl Microbiol 25, 37-45.

Kritzer, J. A., Lear, J. D., Hodsdon, M. E. \& Schepartz, A. (2004). Helical $\beta$-peptide inhibitors of the p53-hDM2 interaction. $J A m$ Chem Soc 126, 9468-9469.

Lelais, G. \& Seebach, D. (2003). Synthesis, CD spectra, and enzymatic stability of $\beta^{2}$-oligoazapeptides prepared from (S)-2hydrazino carboxylic acids carrying the side chains of Val, Ala, and Leu. Helv Chim Acta 86, 4152-4168.

Liu, Z. P., Wang, B. J., Liu, Y. H. \& Liu, S. J. (2005). Novosphingobium taihuense sp. nov., a novel aromatic-compound-degrading bacterium isolated from Taihu Lake, China. Int J Syst Evol Microbiol 55, 1229-1232.

Louws, F. J., Fulbright, D. W., Stephens, C. T. \& de Bruijn, F. J. (1994). Specific genomic fingerprints of phytopathogenic Xanthomonas and Pseudomonas pathovars and strains generated with repetitive sequences and PCR. Appl Environ Microbiol 60, 2286-2295.

Maruyama, T., Park, H. D., Ozawa, K., Tanaka, Y., Sumino, T., Hamana, K., Hiraishi, A. \& Kato, K. (2006). Sphingosinicella microcystinivorans gen. nov., sp. nov., a microcystin-degrading bacterium. Int J Syst Evol Microbiol 56, 85-89.

Pal, R., Bala, S., Dadhwal, M., Kumar, M., Dhingra, G., Prakash, O., Prabagaran, S. R., Shivaji, S., Cullum, J. \& other authors (2005). Hexachlorocyclohexane-degrading bacterial strains Sphingomonas paucimobilis B90A, UT26 and Sp+, having similar lin genes, represent three distinct species, Sphingobium indicum sp. nov., Sphingobium japonicum sp. nov. and Sphingobium francense sp. nov., and reclassification of [Sphingomonas] chungbukensis as Sphingobium chungbukense comb. nov. Int J Syst Evol Microbiol 55, 1965-1972.

Park, H. D., Sasaki, Y., Maruyama, T., Yanagisawa, E., Hiraishi, A. \& Kato, K. (2001). Degradation of the cyanobacterial hepatotoxin microcystin by a new bacterium isolated from a hypertrophic lake. Environ Toxicol 16, 337-343.

Saito, T., Okano, K., Park, H. D., Itayama, T., Inamori, Y., Neilan, B. A., Burns, B. P. \& Sugiura, N. (2003). Detection and sequencing of the microcystin LR-degrading gene, $m l r A$, from new bacteria isolated from Japanese lakes. FEMS Microbiol Lett 229, 271-276.

Schreiber, J. V., Frackenpohl, J., Moser, F., Fleischmann, T., Kohler, H.-P. E. \& Seebach, D. (2002). On the biodegradation of $\beta$-peptides. Chembiochem 3, 424-432.

Seebach, D., Overhand, M., Kühnle, F. N. M., Martinoni, B., Oberer, L., Hommel, U. \& Widmer, H. (1996). $\beta$-Peptides: synthesis by ArndtEistert homologation with concomitant peptide coupling. Structure determination by NMR and CD spectroscopy and by X-ray crystallography. Helical secondary structure of a $\beta$-hexapeptide in solution and its stability towards pepsin. Helv Chim Acta 79, 913-941.

Seebach, D., Abele, S., Schreiber, J. V., Martinoni, B., Nussbaum, A. K., Schild, H., Schulz, H., Hennecke, H., Woessner, R. \& Bitsch, F. (1998). Biological and pharmacokinetic studies with $\beta$-peptides. Chimia 52, 734-739.

Seebach, D., Beck, A. K. \& Bierbaum, D. J. (2004). The world of $\beta$ and $\gamma$-peptides comprised of homologated proteinogenic amino acids and other components. Chem Biodivers 1, 1111-1239. 
Stephens, O. M., Kim, S., Welch, B. D., Hodsdon, M. E., Kay, M. S. \& Schepartz, A. (2005). Inhibiting HIV fusion with a $\beta$-peptide foldamer. J Am Chem Soc 127, 13126-13127.

Takeuchi, M., Hamana, K. \& Hiraishi, A. (2001). Proposal of the genus Sphingomonas sensu stricto and three new genera, Sphingobium, Novosphingobium and Sphingopyxis, on the basis of phylogenetic and chemotaxonomic analyses. Int J Syst Evol Microbiol 51, 1405-1417.

Teorell, T. \& Stenhagen, E. (1938). Ein Universalpuffer für den $\mathrm{pH}-$ Bereich 2,0 bis 12,0. Biochem $Z$ 299, 416-419 (in German).

Tiirola, M. A., Busse, H.-J., Kämpfer, P. \& Mannisto, M. K. (2005).

Novosphingobium lentum sp. nov., a psychrotolerant bacterium from a polychlorophenol bioremediation process. Int J Syst Evol Microbiol 55, 583-588.

Tindall, B. J. (1990). A comparative study of the lipid composition of Halobacterium saccharovorum from various sources. Syst Appl Microbiol 13, 128-130.

Zhang, Y. Q., Chen, Y. G., Li, W. J., Tian, X. P., Xu, L. H. \& Jiang, C. L. (2005). Sphingomonas yunnanensis sp. nov., a novel gram-negative bacterium from a contaminated plate. Int J Syst Evol Microbiol 55, 2361-2364.

Ziemke, F., Höfle, M. G., Lalucat, J. \& Rosselló-Mora, R. (1998). Reclassification of Shewanella putrefaciens Owen's genomic group II as Shewanella baltica sp. nov. Int J Syst Bacteriol 48, 179-186. 